\title{
The Contribution of the Subregional Organizations to the Politics of Integrated Water Ressource Management: Case of the Niger Basin Authority (NBA)
}

\author{
Maiga Aly \\ Department of International Relation, School of Politics and International Studies, Central China Normal University (CCNU), \\ Wuhan, China \\ Email: alymaiga82@yahoo.fr
}

How to cite this paper: Aly, M. (2019). The Contribution of the Subregional Organizations to the Politics of Integrated Water Ressource Management: Case of the Niger Basin Authority (NBA). Open Journal of Political Science, 9, 276-290. https://doi.org/10.4236/ojps.2019.92015

Received: January 30, 2019

Accepted: February 23, 2019

Published: February 26, 2019

Copyright $\odot 2019$ by author(s) and Scientific Research Publishing Inc. This work is licensed under the Creative Commons Attribution International License (CC BY 4.0).

http://creativecommons.org/licenses/by/4.0/

\begin{abstract}
The Niger Basin Authority (NBA) is a subregional organization shared by nine countries of West Africa and the center (Benin, Burkina, Ivory Coast, Cameroon, Guinea, Mali Niger, Nigeria and Chad). The politics of the Niger River water management always remains actuality to reach the objectives of sustainable development. The stakes of the Niger river water resource management are important, because they present themselves in terms of health, food, socio-economic, financiers, environmental, politics and géopolitics. From where the necessity to adopt the IWRM (Integrated Water ResourcesManagement) as a means of sustainable management. It is therefore essential to go through the diagnosis of all the problems related to this water resource in the Niger basin and to make the promotion of a rational and sustainable management, in order to ensure fairness between the different users, a healthy water, the durability of water resource and the fairness of the system; while facilitating the political, social and economic integration between the member states with development perspectives wthin the framework of the shared vision.
\end{abstract}

\section{Keywords}

Contribution, Subregional Organization, Integrated Management, Resource

\section{Introduction}

Water is a natural resource around which turns all life on earth, but it is threat- 
ened seriously nowadays. It is less and less available and exposed every day to multiple dangers that damage it of advantage (the pollution, the blinding and several other curses). It is wasted extensively and is polluted: his quality decreases and his price increases. It becomes a rare resource being always unavailable because used in all socioeconomic activities.

The Niger River is a River shared by nine countries of West Africa and the center (Benin, Burkina Faso, Cameroon, Ivory Coast, Guinea, Mali, Niger, Nigeria, and Chad), and supports life and the subsistence of about 150,000,000 millions people. It is $4200 \mathrm{~km}$ long, 3rd of Africa after the Nil and Congo and 9th of the world, and drains a surface of the order of 2,100,000 $\mathrm{km}^{2}$, also a third of the total surface of the subregional West African.

The low value of the economic potential of the combined basin with strong population dynamics accentuates the phenomenon of poverty in almost all of the basins. On the other hand, the essential of the resource developpement activities in the Niger River basin being carried out in the States to the detriment of the actions of an integrative nature. The Debra focus is to be put, increasingly, on the promotion of the common interest activities. The valorization of the potential of the basin is also confronted to huge problems of financing. The sectors of hydroelectricity and the agricultural hydro amenities, which are very intensive and require external financing, are not yet sufficiently developped.

In Mali, for example, almost all hydroelectric projects are overdue for funding, including projects to implement new plants such as Markala, Kenié and Sotuba II on the Niger River. In Guinea, the Fomi Dam project did not obtain all of its funding for the study of the environment component. Similarly, it should be stressed that funding for the two Taoussa dam projects in Mali and Kandadji in Niger is not completely closed.

It will also be noted that the development of basin resources is largely dependent on external funding; this reflects a low involvement of people and private investors in particular Africans.

In view of these findings, a major challenge is to ensure that the populations of the Niger River basin develop sustainable development, in an environment plagued by resource degradation. This requires all the actors in the basin to have an overall policy and a shared approach to the development of the basin. This also implies having a common policy and a plan of action for the sustainable development of the basin. All this will help to ensure the integration of the Niger basin into the subregional and regional economic spaces.

The Niger River water management policy must cover all the needs of water-related users. It is now subject to poor management which requires an urgent intervention in order to be able to meet the objectives of sustainable development. It is the responsibility of the authorities of the various countries, including the Niger Basin Authority, to set up a management framework for this allocation so that the legitimate needs of the various users are met while preserving the quality of the resource. 


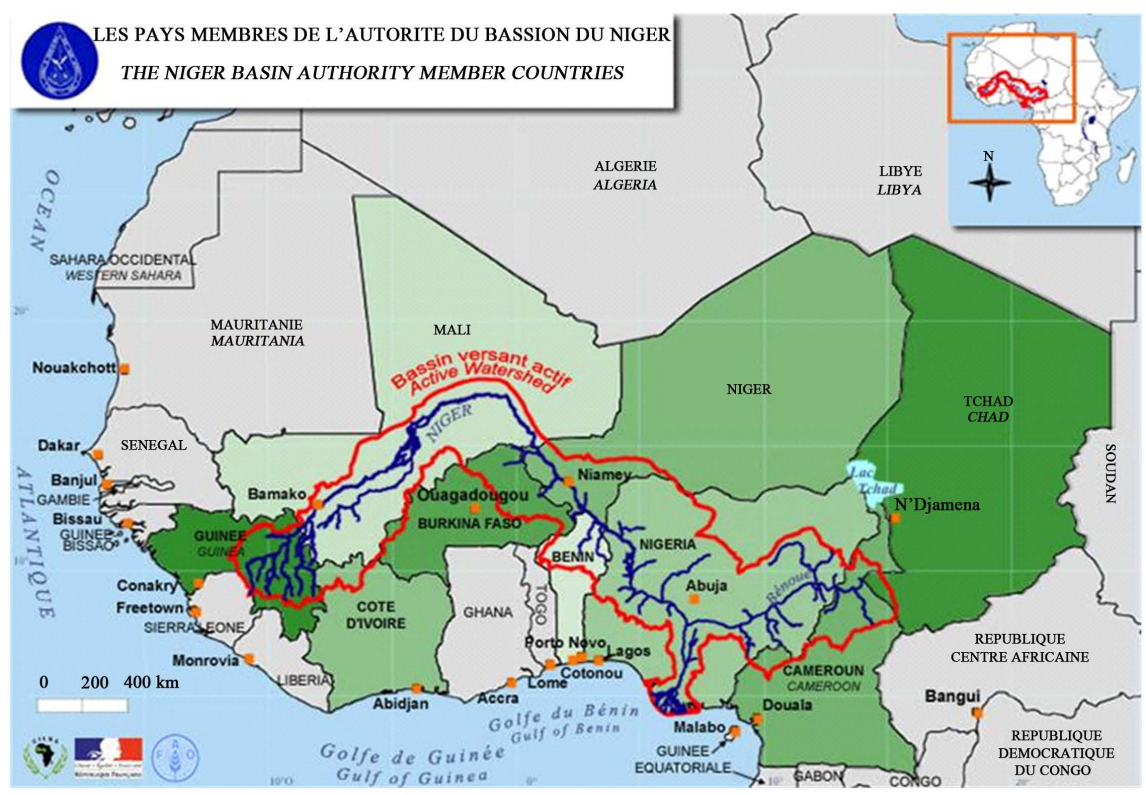

Source: Niger Basin Authority.

\subsection{Problématique}

The current management policy has limitations, particularly in the preservation of aquatic environments. Because the results are mixed, fifty years after independence, a large part of the population does not yet have access to drinking water at a reasonable distance, sanitation in our agglomerations is still far below the expectations of Population and food security is still a major concern of the public authorities. Investments in the water sector are not always coordinated, which leads to situations that are detrimental to the joint effort undertaken over the decades.

The organizations of water users in all the countries of the Niger River basin are confronted with the recognition which for the time being is largely limited to obtaining a title issued by a local administrative authority or National. However, less than $20 \%$ of organizations at the local level have a recognition by an administrative authority. This approach of recognition essentially based on the formal aspect and not taking into account the content of organisations in terms of activities, results produced and contributory capacities to economic and social development cannot To obscure substantive issues such as knowledge of these actors, their sector of activity, their constraints and expectations, and the consideration by States of their importance in national and subregional policies at the basin level.

The total lack of regulation at the regional level of the basin has not encouraged the emergence of organisations at this scale and the few regional organizations of users of existing natural resources do not overlap with the basin's space. The absence of such organizations at the subregional level did not encourage the approximation of user organizations in all sectors with the bodies of the Basin Authority. 
The management system is now faced with a twofold problem: how to manage water resources intelligently and durably, by reconciling the satisfaction of different uses while guaranteeing the natural and heritage functions of aquatic environments in a subregional setting? This study proposes to analyse these different questions in order to give more clarification and to bring in some measures elements of responses to the management policy of the river Niger water resource development engine.

\subsubsection{Objectif Principal}

The main objective of this study is to make it clearer that the policy of integrated water resources management in the Niger River can guarantee sustainable development and facilitate the socio-economic integration of States.

\section{Objectif Spécifique}

Improve the difficulties associated with production systems while supporting environmentally friendly activities.

\subsubsection{Hypothèse Principale}

An efficient management policy and the protection of the Niger River promote sustainable development and subregional socio-economic integration.

\section{Hypothèse Spécifique}

Non-compliance with the regulations and the application for the management and operation of the water resource.

\subsection{Définition of Concepts}

\subsubsection{Contribution}

In the context of this work, the word contribution must be understood: The purpose is to examine the participation of the $\mathrm{ABN}$ in the development of the policy of integrated water resources management in the context of subregional integration.

\subsubsection{Subregional-Organization}

In the context of this work, it is necessary to understand by organisation A (re) grouping composed of States with regional, subregional, international organisational meaning.

An international organization, in the acronym OI, is an association of States, established by agreement between its members and endowed with a permanent apparatus of organs, responsible for pursuing the achievement of common objectives through cooperation between them. They are organizations that bring together in the liberalization of legal entities to coordinate actions affecting several countries.

\subsubsection{Integrated Management}

In the Face of the complexity of water management, the concept of "integrated management" has been developed. The first actors to promote it are international NGO. They all underline, this need "an integrated approach to management 
taking into account all the characteristics of the water cycle and its interactions with other natural resources and ecosystems (...) and also the various services and functions related to water" (Global Water Partnership, 2000). The first characteristic of this method of management is to take into account the complexity of the water cycle as well as the level of use.

\subsubsection{Resource}

The resource term refers to two concepts that must be dissociated: the useful and the used. While renewable resources may be the collection of human activity in certain contexts, this term also covers the production of an "eco-hydro-Geosystem" (Barraqué, 1994). Thus, the perception of the resource as an operating medium should be extended to the conditions of existence and reproducibility of the resource. These two perceptions meet when anthropogenic activity is important. The perception of the concept of resource and that of the concept of the effectiveness of human activity linked to it are closely intertwined. This confusion is also justifie in a management system considering that any resource is accessible to human uses and can lead to exploitation.

\section{Presentation of the Niger Basin Authority}

The establishment of an international cooperation body on the Niger basin dates back to 1963 and is based on the Niamey Act on navigation and economic cooperation between the States of the Niger Basin (Benin, Burkina Faso, Cameroon, Côte d'ivoire, Guinea, Mali, Niger, Nigeria and Chad.).

In accordance with article 6 of the Niamey Act (Basic texts of the NBA, April, 1989), the Niger River Commission (CFN) was established by the agreement of 1964, revised agreement, successively, in 1968, 1973 and 1979 in order to give the institution more efficiency in its interventions.

The establishment of the authority of the Niger Basin itself, dated 1980, by the Convention establishing the authority of the Niger basin. The ABN was put in place in the idea of giving a new impetus to the development of the resources of the basin and in the spirit of the socio-economic integration of the Member States.

The NBA Convention, revised in 1987, grants the institution all the necessary attributes to a cooperative organization at the level of an international river basin, namely:

"Harmonize and coordinate national water resource development policies in the Niger basin;

Participate in development planning through the development and implementation of an integrated basin development plan;

Promote and participate in the design and operation of works and projects of common interest;

In accordance with the Niamey Act, to ensure the control and regulation of all forms of navigation on the river, its tributaries and subtributaries;

Participate in the formulation of requests for assistance and the mobilization 
of funding for the studies and work necessary to develop the resources of the basin."

The establishment of an international cooperation body on the Niger basin dates back to 1963 and is based on the Niamey Act on navigation and economic cooperation between the States of the Niger Basin (Benin, Burkina Faso, Cameroon, Côte d'ivoire, Guinea, Mali, Niger, Nigeria and Chad.).

In accordance with article 6 of the Niamey Act, the Niger River Commission (CFN) was established by the agreement of 1964, revised agreement, successively, in 1968, 1973 and 1979 in order to give the institution more efficiency in its interventions. The establishment of the authority of the Niger Basin itself, dated 1980, by the Convention establishing the authority of the Niger basin. The ABN was put in place in the idea of giving a new impetus to the development of the resources of the basin and in the spirit of the socio-economic integration of the Member States.

The ABN Convention, revised in 1987, grants the institution all the necessary attributes to a cooperative organization at the level of an international river basin, namely:

"Harmonize and coordinate national water resource development policies in the Niger basin;

Participate in development planning through the development and implementation of an integrated basin development plan;

Promote and participate in the design and operation of works and projects of common interest;

In accordance with the Niamey Act, to ensure the control and regulation of all forms of navigation on the river, its tributaries and subtributaries;

Participate in the formulation of requests for assistance and the mobilization of funding for the studies and work necessary to develop the resources of the basin."

The NBA is also endowed with all the bodies to ensure its proper functioning: the Summit of Heads of State and Government, the Council of Ministers, the Committee of Experts and the Executive Secretariat.

From 1980 to the present, the NBA has experienced crisis situations that have not allowed it to move decisively towards its major objectives, namely: the harmonisation of national policies and the elaboration of an integrated development plan for the Niger basin. However it will be held that a new impetus was born in 1998, it strengthened from day to day and thus:

The Paris conference held on 26 and 27 April 2004 around the President of the French Republic and bringing together the heads of State of the countries bordering the Niger adopted the Paris Declaration ${ }^{1}$ so-called: Principle of management and good governance for a Sustainable and shared development of the Niger basin. The heads of State have committed themselves, in particular, to nine (9) principles which mark another departure in the life of the ABN.

${ }^{1}$ Déclaration de Paris avril 2004 relative aux principes de gestion et gouvernance pour un développement durable du bassin du Niger. 
On the margins of this conference, the partners in the development of the Niger Basin Authority have defined a framework for cooperation. Paragraph 4 of the framework of cooperation is of major importance in the new vision around the Niger basin, it states: "All projects and work which Member States would propose to undertake in the basin will be the subject of intervention in Executive Secretariat, in accordance with article 4 of the revised Convention establishing the $A B N$. In the absence of such information and prior notification, projects and works likely to significantly affect the water regime may not be financed by one of the partners."

The authority of the Niger Basin has been the subject of much criticism in relation to its functioning. Indeed, after forty years of existence, the $A B N$ is a succession of financial and/or institutional crises, which explains, but does not fully justify, the inefficiency of the institution.

The $\mathrm{ABN}$ was the subject of multiple restructuring and auditing missions and the last organizational Audit mission (January 2004) concluded as the previous missions "the need for adequate human and financial resources for the proper Functioning of the Niger Basin Authority".

\section{The Achievements of the ABN in the Context of Integrated Water Resources Management}

The ABN took part in a series of organized activities and reflections on IWRM. Like most of the basin organizations in West and Central Africa, it took part in the Ouagadougou conference in March 1998 on the promotion of integrated water resources management (IWRM) in West Africa. ABN also contributed to the development of the regional Action Plan for IWRM in West Africa (PAR/IWRM/AO).

In addition, many of the $A B N$ member countries have embarked on IWRM experience. According to the basic principles, the $\mathrm{ABN}$ is precisely the place indicated for the implementation of IWRM concepts at the scale of the Niger basin.

In considering these ongoing dynamics at the national, regional and international levels in the area of integrated water resources management, it is desirable that the $\mathrm{ABN}$ undertake, as part of the overall basin planning, to promote the IWRM concept for the needs for the sound management of water resources in the Niger basin.

Despite the immense potential that abounds in the Niger River basin, the populations that live there are among the poorest in the world (Blanc-Boge et al., 2007). The region is marked by poverty, rapid population growth and environmental degradation. Yet the Niger Basin offers development opportunities and prospects for the growth of food production, hydroelectric power generation, ecotourism and other related regional development activities.

Despite such a long time of nonchalantness, the $\mathrm{ABN}$ has engaged in actions that have been consolidated over time and are currently an important asset for 
the future of Niger Basin development cooperation, this heritage includes:

$\checkmark$ The Centre for Documentation and information: The Centre was established in 1971 with the support of UNESCO and UNDP. The Centre manages a documentary capital of more than 5000 volumes concerning the Niger basin and its development. The Centre has been modernised and computerised, it is in regular liaison with the documentation centres of the Member States. The Centre regularly produces a bilingual information bulletin (ABN-INFO).

$\checkmark$ The Hydro Niger Programme: This is an activity initiated in the years 80 to prevent flooding of the river Niger; The Programme has progressively installed a hydrometric network with means of automatic transmission, in real time, via satellite, of the collected data; The program also has the modern means of processing, storing and disseminating data. A flood forecasting model in Niger complements the Hydro Niger Programme.

$\checkmark$ Important studies, such as those relating to the degradation of the basin environment (on land erosion in the basin or the development of the water hyacinth), will lead, in the short term, to projects essential for the survival of River.

$\checkmark$ Most recently (2004), the ABN began, with the support of a group of donors including the World Bank, a study process aimed at defining the "shared VISION" that Member States want to give themselves for the future development of the Niger basin.

$\checkmark$ The Convention establishing the ABN, revised in 1987, is, in itself, a fundamental achievement of the $A B N$ in the sense that, by this Convention, the $A B N$ bodies, in particular its executive Secretariat, have all the attributes normally granted to A basin organization, so that, on a legal level, nothing hinders the initiatives of the Institution's officials in all that concerns the development of the Niger basin.

The new momentum due on the one hand to the dynamism of the Executive Secretariat and on the other hand to the interest shown by the international community for the management of water resources in general and in particular for cooperation within the framework of river basins International. It is the result of this international concern, of project funding and of the commitments of political leaders, in particular:

$\checkmark$ The financing of the ABN projects/programmes by the GEF, ADB, CIDA, AFD, MFA, the Dutch bank and Badea.

$\checkmark$ The designation in January 2004 of the Niger Basin as a pilot basin for the integrated water resources management component of the European Initiative "Water for Life".

$\checkmark$ The organization of a Conference of Heads of State and Government on the joint initiative of the President of the Niger, President of the Summit of Heads of State and Government of the ABN and the French President, on the International Partnership for the Niger Basin (Paris, 26-27 April 2004).

The activities of the ABN will take on a significant scale as a result of the 
start-up of a large number of projects, the results of which will be essential in the implementation phase of the Niger Basin Sustainable Development Action Plan (SPSD). These projects in the process of being started are:

$\checkmark$ Strengthening the Hydro Niger Programme under the guise of Niger-Hycos with multiple funding: Badea, AFD, the World Bank and the Dutch bank.

$\checkmark$ The coordinated implementation of the anti-siltation programmes in the Niger Basin (ADB funding II) to reverse the trend towards land and water degradation in the Niger Basin (GEF funding).

$\checkmark$ The technical Assistance of the ABN/ACMAD/AGRHYMET Consortium in the integrated water resources management of the Niger basin,

$\checkmark$ The updating and extension of the simulation model of the flows of the Niger River (AFD financing).

$\checkmark$ The availability of a study fund (AFD financing) to the ABN.

The future projects of the ABN will be defined by the studies on "shared Vision" and those that will enable the development of the spsd of the Niger basin. The Paris declaration of the Heads of State and the Protocol signed by the development partners of the NBA suggest that the continuation of the planning process for the development of the basin and the presentation of its water resources depends only on the capacity of the ABN leaders to mobilize and organize, effectively, the commitments made by the partners.

\section{The Political Evolution of International Relations between Member States}

Created in 1980 on the ashes of the Niger River Commission (1964), the Niger Basin Authority (ABN) aims to promote cooperation among member countries and to ensure an integrated development of the basin.

The ABN is credited with many studies that are unfortunately not translated into concrete achievements for the welfare of the riparian populations. This situation led to the higher bodies of the ABN (Council of Ministers and Summit of Heads of State and Government) to take, during their consultations from December 2000, the decision that a clear and shared vision be developed in order to Create an environment conducive to cooperation and develop an Action Plan for sustainable Development (SPSD) accepted by all players in the basin. This will was once again reaffirmed by the 7th Summit of Heads of State and Government held in Abuja in February 2002.

Thus, the Member States of the ABN adopted the Niamey declaration of 12 September 2003 on the process of developing a shared Vision for the sustainable development of the basin, intended to provide a consensual and resolute basis Strategic Guidance Co-operative for the development of a long-term action plan for the development and rationalization of basin resources.

The shared vision consists of an overall vision of Niger's development, negotiated and accepted by all the Member States ${ }^{2}$. This is the ideal to highlight the potential of the whole basin desired by the members. This ideal is not an arith${ }^{2}$ Processus d'élaboration d'une vision partagée pour le développement durable du bassin du Niger. 
metic sum of the development actions desired by each of the individual states. Rather, it is an integrated development scheme that is as rational as possible for the maximum development of all the resources of the Niger basin in order to generate the greatest number of benefits for all the Member States.

The shared Vision will need to reflect the commitment of States to a joint action programme that defines long-term objectives (Horizon 2025) and provides the strategic directions for the specific mechanisms and tools developed to achieve these goals.

The process of shared Vision stems from a willingness to unite efforts to meet the many challenges of basin development. This process must be iterative with a technical analysis that inventories, analyses and summarizes existing opportunities for inclusion in a logical framework of the basin SPSD. Taking into account the activities included in the $\mathrm{ABN}$ mandate, multi-sectoral studies were carried out in the nine (9) ABN countries to identify opportunities and constraints to the development of the basin. The development of the Niger Basin first requires a common understanding of the problem, the opportunities and constraints of the basin. This common understanding is based on the results of the studies carried out at the basin level and accepted by all countries. It is unanimously established that the Niger basin has immense potential that is still little or poorly exploited.

The concerted exploitation of resources will take place on the basis of enhanced cooperation between countries. This cooperation must be exemplary and particularly with regard to cross-border shared resources. Through the Paris Declaration signed in April 2004, Member States undertake to cooperate on a basis of solidarity and reciprocity, taking into accounts the previous agreements and the means of new agreements with a view to developing and implementing policies, Programs and projects initiated in all or part of the basin.

The exploitation of the water resources of the basin is made nowadays in a mainly sectoral way by each of the Member States. For the rational and sustainable development of these resources for the benefit of the present and future populations, it is necessary to put in place mechanisms to establish an integrated management of water resources, i.e. a management that takes Consider all facets (political, institutional, social and technical) of water issues and related activities in the basin. This form of exploitation is likely to improve the living conditions of the populations.

The constant support of the development partners is necessary for the development of the basin. This support was reaffirmed through the cooperation framework of the Niger Basin Authority Partners signed in April 2004. In the development framework of the Niger basin, each country has defined its development priorities. The activities and programmes conducted so far in the Niger basin are mainly country-based initiatives. This practice has shown its limitations, the use of integrative projects to support the actions undertaken, could allow a better development of the basin. The priorities expressed so far by countries could become more and more regional in nature. The implementation of 
integrator-oriented projects would allow better exploitation of the basin's resources and ensure sustainable development. This guidance would assist the ABN in the development of the Sustainable Development Action Plan (SPSD) accepted by all stakeholders in the basin.

The development of the basin first requires a consensus on the problem of basin development (Barreteau, 2007). The many studies that have been carried out so far make it possible to reach this consensus. The concerted management of resources makes it possible to make the most of it and to improve the living conditions of the people. This vision is a common and accepted perception of the countries and all the partners in the basin development process.

The shared Vision can be seen as a common appreciation and accepted by all on the issues and challenges of the basin (the basin is full of great potentials waiting to be exploited), on the development guidelines of the basin (the Prote Ction and the development of the basin's resources and in particular water) and on the major priorities of the basin's expansion (with an increasingly marked trend for integrative priorities).

On the basis of the actions carried out and the above-mentioned proposals, the work of the regional validation workshop of the regional Synthesis Study report, held in Bamako from 25 to 29 January 2005, culminated in the draft shared Vision statement.

The shared Vision is thus seen as the image that all the actors can have from the basin to the 2025 horizon. It is seen as a common and shared vision on all aspects of basin development and takes into account the imperatives of sustainable development to cover the temporal and geographical aspects of development. This shared Vision is based on the overall understanding of the stakeholders on the issues, challenges and challenges of basin development. It therefore reflects the common and accepted vision of the actors on the development of the basin on the 2025 horizon.

\section{The Development of Socio-Economic Integration in the Basin}

The process of building planning for basin development on a forward-looking and participatory approach requires, on the part of all the players in the basin, an overall vision and a shared approach to the development of the basin.

Therefore, the confirmation of States in a national approach to development projects has not so far allowed carrying out a joint exercise to assess the potentialities and needs and to carry out a comprehensive planning of Investments to be made, sharing of costs and profits, etc. Such a situation can only accentuate upstream/downstream frustrations as well as the risks of conflicts between users within the same country and between countries all things damaging to the construction of a common future at the basin level. The future of the basin will have to emerge from this national logic in terms of development projects and take into account the basic needs of the populations, their initiative and their adherence 
to the actions to be put in place. There will be no common and best future at the basin level if this condition is not fulfilled. The existence of dams and deductions management committees in the national portions of the basin is to be strengthened with support for the revitalization of these management committees and their structuring not only at the local level but also at the national level and regional basin.

The presence of international non-governmental organizations (NGO) and international networks has certainly been an emulation for the emergence of local associations and national NGO, but it is in the long run a problem of positioning the latter towards the sources of funding. In fact, several funders have been undertaking the deconcentration of credits on local financing machines in the southern countries over the past few years. The search for funding pushes several NGO and international networks to émarger on these local counters as well as local and national NGOs and networks. Of course, the expertise of older and better-equipped international NGOs makes them the main beneficiaries of these decentralised financings in addition to those mobilized directly to the north.

As for NGO, local and national networks, financial survival leads them to move away from their primary vocation and mission such as: social mobilization, awareness raising, development education, the provision of various services to members (DIS Defence of interests, access to training, ... etc.), dialogue with other actors such as the state, decentralised communities, ... etc.

These two situations did not allow the development of a real local network capacity of natural resource user organizations in the basin countries. In any event, international organisations and networks must accept to confine themselves to the supporting role and avoid the representation in place of the local, national organisations which they support.

Despite all these difficulties, users of the pool's natural resources organized or not in groups, associations, unions or federations constitute the first force and energy on which any sustainable development policy will have to Build. It is "The first raw material" and the basic unit of development; all the institutional actors involved at the basin level should take this as an essential element of the action.

The most remarkable fact about this is the large dam projects in the various countries of the Niger River basin. Most countries have major projects in hydro-agricultural and/or hydro-electric facilities. All these projects, some of which date back several decades, have not been the subject of actual prior consultation of the populations of the affected areas on the site or downstream. On the basis of the very simplistic assumption that these projects have only positive spillovers, is it sufficient for the opinion of the populations to be affected and who will benefit from these benefits to be obscured? Such an approach to the central level of States, as a general rule initiator of these major development projects, can only hinder the accession and mobilization of the populations for the success of these projects. In some countries, people who have lived for cen- 
turies on land they consider their own refuse to move and are strongly opposed to the realization of these projects. While acknowledging the need to undertake actions to enhance the potential of the basin to improve food security, energy security, etc., users of natural resources believe that action will have to start small Size on their soil, in their fields to improve agricultural yields, to increase the foraging potential, to improve the supply of drinking water, to increase the incomes of families, to ensure the supply of electricity..., etc.

These considerations are independent of those working on a cross-border approach to these major projects which have an influence on the water regime thus on the ecosystems and societies of the downstream countries. That is why the process of shared Vision has been initiated.

No involvement of the actors of civil society is possible if the state actors of the basin who provide the leadership of the action are not aware of the necessity and importance of this participation (Global Water Partnership, International Network of Basin Organizations, 2009). Everything should start there. The vast majority of the States and the people who animate them must make a change of strategy with regard to the participation of the people and not perceive it as a counter-power to state public action. It remains understood that users have a duty of citizen control of this state public action and this is recognized by the law.

The participation of populations is also a necessity as the first resource on which the state can build. In all the countries of the Niger River basin, all national development policy and guidance documents place the participation of the population as an essential pillar and the approaches implemented in the field of projects and Development programmes highlight the involvement and participation of the population in the initiative and the responsibility of the action.

The authority of the Niger River basin will have to retain the involvement and participation of the population in the sustainable development dynamics of the basin as an obsession and a result to be achieved in its action towards the Member States and users of Natural resources themselves. The great tradition of governance of "high" in "low" practiced by key development actors since independence is called to change to promote the participation of grassroots actors in decision-making processes.

Developing and adopting a shared Vision formulation on which basin development planning is based is a major issue. To this end, it is important for ABN to work towards the success of the partnership with the World Bank and other development partners as part of the shared Vision process for developing a development action Plan (SPSD) of the basin.

The increase in human activity poles coupled with climatic hazards leads to an accelerated degradation of the basin's resources and environment. This leads to the question of how to ensure sustainable development on the basin, considered a common heritage, and that sees its resources deteriorate. The national portions of the basin are often landlocked and this limits their integration into the national economy. At the subregional level, the beginnings of integration exist 
through the multiple bilateral or multilateral cooperation agreements between the countries of the basin.

Although the basin has enormous potential in natural resources, it nevertheless suffers from a weak integration of its economy at the national, subregional and international levels. The exploitation of the comparative advantages of the basin must also be put in perspective with the integration opportunities available to the basin economically: large market, food security, energy supply etc. In the context of integration, the basin can, for example, find its place as a large producing region, particularly in the agropastoral domain.

At the international level, the Niger basin suffers from the same constraints that countries face in their efforts to participate in the global economy. From all these considerations, the integration of the Niger basin into the economic spaces: National, subregional and international, is a major issue of economic and social development.

Despite the natural heritage of the basin, the populations that live there face considerable challenges. The current situation in the basin is characterized by population explosion, poverty and environmental degradation. Most of the countries in ABN are among the poorest in the world. The basin should see its population double within 20 years, which will further contribute to water resources and other natural resources. Yet the Niger Basin has assets for the implementation of development activities to win on all tables and to strengthen the supply of energy, agricultural production, transport, environmental protection and well other aspects related to the development of the basin. Concerted management of water resources could also play a catalytic role for greater economic integration in the region.

The Niger basin consists mainly of poor countries, some of which are landlocked, and subjected to repeated droughts in recent decades. They are evolving in a difficult economic environment with an economy dominated by agriculture and livestock that occupy 80 to $90 \%$ of the population. The many economic activities in the basin are directly dependent on the exploitation of natural resources.

Can this system of socio-economic development in particular significantly improve the living conditions of the populations of the basin?

\section{Conclusion}

The Niger River basin is full of huge development opportunities around which all the member countries of the basin must strengthen their cooperation framework, and the consolidation of new means of development and management of shared natural resources, in particular water and the development of management principles and good governance for sustainable development of the Niger basin.

Resource development and the development of the basin also require increasing involvement of private operators in particular in Africa. The funding of basin 
development activities and the participation of civil society actors, especially women and young people, should be organized in combination and priority.

Can subregional organizations ensure the development of decisive actions in the basin without the effective support of member countries?

\section{Conflicts of Interest}

The authors declare no conflicts of interest regarding the publication of this paper.

\section{References}

Barraqué, B. (1994). Problématique sociologique de la gestion intégrée des rivières. In C. Le Coz (Ed.), Gestion intégrée des milieux aquatiques. Actes des Cinquièmes journées du Diplôme d'Etudes Approfondies Sciences et Techniques de l'Environnement (pp. 9-21). Presses de l'école nationale des Ponts et chaussées.

Barreteau, O. (2007). Modèles et processus de décision collective: Entre compréhension et facilitation de la gestion concertée de la ressource en en eau (85 p). Mémoire pour l'obtention de l'habilitation à diriger des recherches, spécialité Informatique, Université Paris Dauphine, CEMAGREF.

Blanc-Boge, A., Carron, D., Pouradier Duteil, S., \& Schmidt, P. (2007). Les politiques de l'eau au coeur du développement durable (p. 44). 3èmes rencontres d'experts de l'Observatoire du secteur public local. Institut d'Etudes Politiques de Lyon, 30 Janvier 2007.

Global Water Partnership (2000). Integrated Water Management (80 p). Tac Background Paper No. 4, Stockholm: Comité technique consultatif.

Global Water Partnership, International Network of Basin Organizations (2009). A Handbook for Integrated Water Resources Management in Basins (112 p). Stockholm: Elanders. 